\title{
Nefarious Activities: To Disclose or Not to Disclose
}

\author{
Malcolm Shelton-Agar and Helen Cruse
}

It is well established that insurance contracts are contracts uberrimae fidei (of the utmost good faith). From this foundation, derives the insured's duty to disclose facts material to the proposed risk. This duty is placed upon the insured because s/he normally has the best knowledge of facts material to assessing the risk.

In New Zealand today, whether a fact is "material" (and therefore needs to be disclosed) is based upon the view a "prudent insurer" would take of it. While the insured will usually know the all of the facts relevant to an assessment of the risk, s/he will often not know which of those facts would be of importance to a "prudent insurer". Confusion on such issues has given rise to considerable case law in the area.

This article first examines what must be disclosed at common law - which of a general range of "nefarious activities" an insured owes it to his/her insurer to come clean about. The range and breadth of what must be disclosed would surprise most insured parties. Secondly, the article examines situations where insured parties are relieved of the general disclosure obligation what is at common law capable of being material might not need to be disclosed in specific situations - including situations where the conduct of insurers or wording of the proposal (or other insurer supplied documents) might allow an insured to escape the general duty.

\section{WHAT MUST BE DISCLOSED?}

\section{A Different Types of "Nefarious" Activity}

A prospective insured is obliged to disclose to the insurer all facts which a prudent insurer would consider material. ${ }^{1}$ The test is like that in $s 6$ of the Insurance Law Reform Act 1977 (a material fact is one which would have influenced the judgement of a prudent

* Barristers and Solicitors of the High Court of New Zealand.

1 The State Insurance General Manager v McHale \& Anor [1992] 2 NZLR 399, 406 (CA); (1992) 7 ANZ Ins Cas 61-102, 77,433. 
insurer in fixing the premium or determining whether and/or upon what terms to take the risk). However, s 6 deals with cases of misstatement as opposed to non-disclosure. ${ }^{2}$

What affects the mind of a prudent insurer in one case may not affect it in others. It has been noted that what is material in a given case, "...can only be determined in the light of all the circumstances existing at the time the proposal is completed or the insurance is otherwise proposed for." 3

Therefore every case is to some extent a decision on its own facts. A definitive summary of the situations where certain matters become "material" is beyond the scope of this article. The goal of this section is to consider the types of "nefarious activities" that are capable of being material if the facts otherwise support that conclusion.

Prospective insureds may have any number of things in their backgrounds:

(a) Convictions;

(b) Acquittals;

(c) Unresolved charges or accusations;

(d) Undetected criminal activities;

(e) Activities which, while not illegal, were imprudent (such as high handed commercial activity).

Also, of the convictions, acquittals and charges, some may be justified or unjustified. An insured may have been wrongly convicted, acquitted or charged. The question is where to draw the line with the disclosure obligations.

\section{B Materiality to the Prudent Insurer}

If materiality to the prudent insurer is the only relevant consideration, the disclosure obligation is capable of being extremely wide. In March Cabaret, ${ }^{4}$ the Judge thought that acquittals (where incorrectly acquitted) and charges (whether the insured was innocent or not), should be disclosed: 5

2 Above n 1, 403; 77,431.

3 Misirlakis \& Anor $v$ The New Zealand Insurance Co Ltd (1985) 3 ANZ Ins Cas 60-633 (CA), 78,897.

$4 \quad$ March Cabaret Club \& Casino Ltd v The London Assurance [1975] 1 Lloyd's Reports 169.

5 Above n 4, 177. 
This decision was criticised in Reynolds. ${ }^{6}$ In that case, Forbes J considered there was no obligation on an innocent person to disclose a charge. However, he did believe the following should be disclosed:

(a) Convictions (whether or not the insured had committed the offence);

(b) Acquittals (where incorrect);

(c) Charges (where the insured had committed the offence);

(d) Undetected criminal activity.

His standpoint appeared to be that where the insured was innocent there was no effect on the moral risk but where the insured clearly had done something wrong, disclosure should be made. The exception was his view, discussed below, that a conviction should be disclosed even if the insured had not committed the offence. The Reynolds approach appears to have been accepted in New Zealand. For example, in Gate, ${ }^{7}$ Fisher J expressly approved the Reynolds approach regarding mere allegations of dishonesty, saying, "...materiality will turn upon the facts underlying the allegations, not the allegations themselves." 8

Considerable authority also exists for undetected criminal activity being material and needing to be disclosed. ${ }^{9}$ In fact, insurance experts appearing in both Quinby ${ }^{10}$ and Gate ${ }^{11}$ gave evidence that undetected dishonesty is in fact more material to a prudent insurer than detected dishonesty because it may show that the insured was too clever to be caught!

Not all of the potential disclosure situations outlined in Reynolds have come up for consideration in New Zealand. If they do the approach of New Zealand courts to date suggests the same stance will be taken on most of them. Arguably, the only problematic situation raised by Reynolds is the need to disclose a criminal conviction where the offence was not in fact committed. In practice, this issue would rarely arise. Proposals usually specifically ask about convictions (in which case it is not suggested the insured lie). However, if the issue arose, and if Fisher J's statement in Gate about materiality turning

6 Reynolds $v$ Phoenix Assurance Co Ltd [1978] 2 Lloyds Rep 440.

7 Gate $v$ Sun Alliance Insurance Ltd Unreported, 19 January 1994, High Court, Auckland Registry, CP 1218/92.

8 Above n 7, 42.

9 See, for example, Quinby Enterprises Ltd (in liq) $v$ The General Accident Fire \& Life Assurance Corporation Public Limited Company Unreported, 28 November 1994, High Court, Auckland Registry, CP 618/89 (relating to nondisclosure of undetected, or at least unprosecuted offences relating to the issue of securities); Gate, above $n$, (relating to a number of fraudulent activities which $\mathrm{Mr}$ Gate had not been charged with or convicted of); King $v$ NZ Insurance Co Ltd [1993] DCR 31 (relating to an undisclosed drug addiction).

10 Above $\mathbf{n} 9,48$.

11 Above n 7, 41. 
upon the facts underlying the matter is accepted, then it seems logical than an insured need not volunteer information about an incorrect conviction. The insured would know that the conviction was not representative of any moral hazard which would be of interest to an insurer. Of course, if the insured was challenged on discovery of the conviction, it would be difficult to establish their innocence. They would have already failed to establish their innocence on the criminal standard (which should have been easier to do).

It is the existence of the moral hazard which underlies the disclosure obligation. Therefore it is irrelevant whether that moral hazard has been reflected in a conviction, a charge, or neither. It is the fact of the moral hazard and its impact on risk which is the essential element. Accordingly there is also no reason in logic why even non-criminal but highhanded behaviour reflecting moral turpitude could not impact on risk and be subject to the obligation to disclose. The scope of matters potentially subject to a disclosure obligation is extremely wide.

\section{Human Rights-based Challenge to Wider Disclosure Principle}

Regardless of what a prudent insurer may consider material or not, some consider it unfair that matters such as undetected offences must be disclosed. Some debate has centred on the relevance of the privilege against self-incrimination and presumption of innocence in the disclosure context. Should these principles mean an insured should not have to disclose undetected criminal activity or unresolved charges?

The matter arose for consideration in March Cabaret. There, at the time of policy renewal, the insured failed to disclose an outstanding charge for receiving and handling stolen property. He was later convicted of the offence and a subsequent unrelated claim under his policy was declined for non-disclosure. May J held that the outstanding charge was material and should have been disclosed. He said: ${ }^{12}$

In the light of some of the evidence...I was concerned at one stage in this case about how one could reconcile the presumption of innocence and the privilege of non-incrimination with the duty of disclosure on the facts as I have outlined them. After argument I realize that my doubts were based upon a fallacy. One must remember that there is no estoppel by acquittal save as between the Crown and the person acquitted. There is nothing to prevent one party to civil proceedings, if the fact be material and relevant, attempting to prove that another party to those proceedings has in truth committed a crime of which that other party has been previously acquitted in a criminal court...Thus, even if [the insured] had been acquitted prior to the renewal...there would in this case have been nothing to prevent insurers attempting to prove that he had nevertheless committed the offence. If they had succeeded and if [the insured] had, as here, failed to disclose that he had committed the offences, then this would, 
notwithstanding his acquittal, have been a material non-disclosure entitling the insurers to avoid the policy. No one has a right to a contract of insurance, and if a proposer has committed a criminal offence which is material and ought to be disclosed he must disclose it, despite the presumption of innocence, which is only a presumption, and despite the privilege of non-incrimination, which is only a privilege - or he must give up the idea of obtaining insurance at all.

One writer criticised May J's "dismissal" of the privilege against self-incrimination and presumption of innocence saying of them: ${ }^{13}$

They are of far greater importance than the principle of non-disclosure itself, for to destroy them is to destroy the basic principles upon which our system of justice is based.

But are those principles in fact weakened by wide disclosure law? Arguably, as outlined below, they are not.

\section{Privilege Against Self-Incrimination}

The privilege has been stated as follows: ${ }^{14}$

The rule is that no one is bound to answer any question if the answer thereto would, in the opinion of the Judge, have a tendency to expose any deponent to any criminal charge, penalty or forfeiture which the Judge regards as reasonably likely to be preferred or sued for.

While the privilege is normally claimed in judicial proceedings, it is capable of application outside that arena if there is an obligation to answer questions, give information, or disclose or produce documents imposed by statute. ${ }^{15}$

There is some doubt as to the origins of the privilege. It may have been rooted in the common law or canon law. Traditionally, however, people believe it to have arisen in response to unjust inquisitorial procedures common in England in the early 17th century (used for example in the Star Chamber and High Commission proceedings). Suzanne $\mathrm{McNichol}$ argues that since so many misunderstandings have arisen in relation to the privilege and since the reason for the protection it originally offered has largely disappeared, it should now be "re-thought" in a modern setting. ${ }^{16}$

$13 \mathrm{CCH}$ Australian \& New Zealand Insurance Reporter, Vol 1, 11-103.

14 Blunt v Park Lane Hotel Ltd [1942] 2 KB 253, 257.

15 Taylor v. NZ Poultry Board [1984] 1 NZLR 394 (CA).

16 S B McNichol Law of Privilege (Law Book Co, Sydney, 1992) 137-138. 
However, to the extent the privilege's normal application and history are relevant, a few things are apparent when considering its application in the insurance disclosure arena:

(a) Insureds generally have no statutory obligation to disclose certain matters to an insurer. This scenario therefore falls outside the application of the privilege as described in the Taylor decision. Note that in the marine insurance area there is a statutory obligation: s18 Marine Insurance Act 1908;

(b) The privilege is designed to prevent people being compelled to disclose matters against their interest by people in power. An insured is not compelled to disclose anything to an insurer. A prospective insured is free to completely avoid dealing with the insurer ;

(c) As a prospective insured cannot be compelled to disclose anything, $s / \mathrm{he}$ is also free to say to an insurer "there are some matters I may be obliged to disclose to you, however, I decline to do so on the grounds it may incriminate me". The privilege then remains intact. Of course, the insured is unlikely to get insurance on that scenario but that is the insurer's right.

It seems clear that the privilege against self-incrimination will not be infringed upon in any way by wide disclosure obligations. If those disclosure obligations practically make insurance unavailable to some people, that is better than allowing an amorphous principle of uncertain origin to preclude insurers from obtaining the information necessary to strike a fair commercial bargain.

If the privilege against self-incrimination was intended to be such a basic and farreaching right, it is surprising that it was not given any such general effect in recent human rights legislation (such as the New Zealand Bill of Rights Act 1990, the Human Rights Act 1993 and the Privacy Act 1993). Of course, s 28 of the New Zealand Bill of Rights Act does provide that an "existing right or freedom" shall not be abrogated or restricted by reason only that it is not included in the Bill of Rights or is only partly included. However, that is a weak foundation for arguing such a wide application of the principle.

The most "generally expressed" statutory expression of the principle is contained in s 4 of the Evidence Act 1908. This section, after providing that certain parties are compellable witnesses, states: "nothing herein shall render any person compellable to answer any question tending to criminate himself". However, as stated in Cross on Evidence, this provision "...is best regarded as having been inserted ex abundanti cautela in order to preclude any argument that $s 4$ overrode the old common law privilege." 17 It is not an appropriate weapon in the argument for wide application of the common law privilege. 
In summary the privilege against self incrimination does not provide a basis for an insured not to disclose an otherwise material fact. However if Barker J in Quinby is correct the privilege may still be available to diminish the usefulness of the disclosure obligation to the insurer. In Quinby, Barker J referred to having warned the insured that he was not obliged to answer any questions if to do so would incriminate him. ${ }^{18}$ Apparently the insured availed himself of this right on a number of occasions. Barker J was ultimately able to find on the evidence before him that there had been material non-disclosure. That however begs the question of what would have happened if the only person who had sufficient probative knowledge of the nefarious activities was the insured and at the hearing $s /$ he claimed the privilege. In those circumstances, notwithstanding a prima facie breach of the disclosure obligation, the insurer would be incapable of adducing evidence as to the materiality of the non disclosure. This raises the question of why, if the privilege is not available at the point of negotiating the contract, it should be available in proceedings dealing with the obligations arising under the contract?

\section{E Presumption of Innocence}

It also makes little sense for the "presumption of innocence" principle to shield dishonest insureds from having to disclose activities falling short of convictions. The presumption of innocence is simply a rule as to onus or burden of proof. ${ }^{19}$

It applies between prosecution and accused in criminal proceedings. Even if an insured did admit something to its insurer for the purposes of obtaining insurance the presumption of innocence would still apply and the onus would still be on the prosecution to establish guilt if that admission was subsequently used in criminal proceedings. The presumption is merely an evidential principle not an official legal "slate-cleaner". While the presumption in its classic more limited sense, is recognised in the New Zealand Bill of Rights Act (s 25) there is no wider acknowledgement of it in recent human rights legislation.

\section{F Practicalities and Way Forward}

Whatever the merits of allowing insurers the opportunity to get this wider range of information, it does place applicants for insurance in a very difficult position. Also, as noted by one author, "Not only will they often be unaware of legal technicalities but, having regard to human nature, few people would attempt to abide by it." 20

18 Above n 9, 12-13.

19 R A McGechan Garrow and McGechan's Principles of the Law of Evidence (7 ed, Butterworths, Wellington, 1984) 183.

20 Above n 13, 11-104. 
With regard to this "compliance problem", it may be possible to alleviate some people's concerns with an undertaking in the proposal. That would be to the effect that information given to the insurer in connection with the proposal would not be used by the insurance company for any other purpose or disclosed to anyone outside the insurance company. (Without such an undertaking, it appears insurance companies may be free to disclose the information about undetected offences and the like. Principle 11(e) in the Privacy Act creates an exception to the usual non-disclosure rule where disclosure is necessary to avoid prejudice to the maintenance of the law, including the detection of offences).

The fact that most insureds would not appreciate that such information must be disclosed is a serious problem. Associated aspects of it are dealt with in the next section. At this stage, however, it is simply worth noting that a remedy of that problem is likely to require legislative intervention. The problem is dealt with in Australia, for example, by a modification of the test for materiality. In Australia, by virtue of $\mathbf{s} 21$ of the Insurance Contracts Act 1984, materiality is determined more on the views of the reasonable insured than the prudent insurer. It provides (in part):

Subject to this Act, an insured has a duty to disclose to the insurer, before the relevant contract of insurance is entered into, every matter that is known to the insured, being a matter that:

(a) the insured knows to be a matter relevant to the decision of the insurer whether to accept the risk and, if so, on what terms; or

(b) a reasonable person in the circumstances could be expected to know to be a matter so relevant.

The former President of the Court of Appeal, Sir Robin Cooke (as he then was), has already suggested that New Zealand follow Australia's lead on this issue. ${ }^{21}$ Interestingly, also, he commented that it may be open to the Court of Appeal sitting as a Court of five (not three, as in McHale) to overturn the common law prudent insurer test in favour of a reasonable insured type test. ${ }^{22}$ One day, an insured, in a case worth the risk, may try that on. However, until that happens, or until appropriate legislation is passed, insurers must be fully entitled to take the benefit of the existing common law position (subject to matters raised in the following section).

21 Above n 1, 405; 77,433.

22 Above n 1, 404; 77,432. 


\section{CHALLENGING THE GENERAL DISCLOSURE OBLIGATION}

\section{A The Criticism of Insurers}

There may be little doubt that many of the activities described above would be material to a prudent insurer. However, as seen above, the subtleties of the law in this area have escaped the notice of many insureds. Insureds tend, not surprisingly, to believe that insurers are only interested in what they ask about in the proposal. This state of affairs can result in some people, in all good faith, breaching the duty of disclosure, which is itself founded on the need to exercise good faith. Where this results in no insurance payment after a legitimate and unrelated loss, the insurer then comes under attack.

As noted in Barclay Holdings, ${ }^{23}$ it is of course open to insurers to protect themselves by suitably framed questions in a proposal if such matters interest them. And, an insurance contract is after all "one of mutual good faith". 24

Case law suggests that where insureds find themselves in the position of having a policy avoided for non-disclosure of a legally material fact, one or more of three main challenges may be made. The insurer may be alleged to have:

- Breached its duty of good faith;

- Breached the Fair Trading Act; or

- Waived the need to disclose the information.

These three possible arguments are dealt with below.

\section{B Breach of the Duty of Good Faith}

This argument was raised in McFarlane. ${ }^{25}$ The insured argued that the insurer would have known ${ }^{26}$ what was capable of being considered material and that few proponents disclosed such matters unless requested in a particular way but, in effect, set a trap for the insured by not letting him know about it.

23 Barclay Holdings (Australia) Pty Ltd $v$ British National Insurance Co Ltd (1987) 8 NSWLR 514.

24 Above n 23, 519.

25 McFarlane t/a Grove Contractors $v$ The State Insurance Office General Manager (1989) 5 ANZ Ins Cas 60-887.

26 Above n 25, 75,663. 
The argument did not find favour with Eichelbaum J who stated: ${ }^{27}$

If the insurer sets a trap by ambiguous questions, then the defence will fail. Otherwise, if in accordance with established principles the insurer discharges the onus of proving that there has been non-disclosure of a material matter, the insurer is entitled to avoid the policy.

However, it received some (obiter) support in State Insurance $v$ Peake. ${ }^{28}$ While Chilwell J ultimately held for the insured on another ground, he noted his disagreement with Eichelbaum J's view: ${ }^{29}$

In McFarlane's case, Eichelbaum J considered the practice of insurance companies in refraining from asking about general convictions and then seeking to avoid the contract for non-disclosure of that very matter. He was not prepared to hold that this was a deliberate device to avoid liability. As the position now stands, however, there have been three cases before the Courts, all within the last six months, all involving the same appellant, all involving a substantially similar insurance policy, and all seeking to avoid liability on the same basis. Certainly in the present case there is every indication that had the respondent been asked the question in respect of which non-disclosure is alleged, she would have given an honest response. In all the circumstances I accept that there is some force in counsel's submission that such a practice is inconsistent with the duty of utmost good faith.

It appears there has yet to be a New Zealand case deciding whether the insurer has, as part of the duty of good faith, an obligation to enquire as to previous convictions. In the recent Quinby case, Barker J (in another context) cited with approval the passage from Eichelbaum J's judgment which dismissed the argument. However, those interested in running the argument would be encouraged by the Court of Appeal decision in the Gate case. ${ }^{30}$ Again, while it was not necessary to decide the case, the Court of Appeal stated: ${ }^{31}$

Good faith obligations apply to insurers as well as insureds. It is at least arguable that, in the commercial and social environment of the mid 1990s where insurance coverage is sought throughout the community and insurers pride themselves on providing simple plain language covers, those insurers concerned about moral risk should put their cards on the table and signal that fair and accurate answers to all questions in the proposal may not discharge the proponent's disclosure obligations.

27 Above $\mathbf{n} 25$.

28 [1991] 2 NZLR 287.

29 Above n 28, 295.

30 Gate $v$ Sun Alliance Unreported, 5 April 1995, Court of Appeal, CA 37/94.

31 Above n 30, 23. 
With that endorsement, the good faith argument may yet prove an effective weapon for insureds. Thus, from the insurers' point of view, it may now be prudent to insert warning provisions in their proposals to the effect suggested by the Court of Appeal.

\section{Breach of the Fair Trading Act}

Arguably, where an insurer refrains from asking certain questions in a proposal, fails to warn the insured as to his/her duties and the consequences of their breach, then subsequently avoids the policy for non-disclosure, its conduct could be said to be "misleading or deceptive conduct or conduct likely to mislead or deceive" under $\mathrm{s} 9$ of the Fair Trading Act 1986.

The idea received some initial enthusiasm from Judge Inglis QC in the King decision. The matter appears to have been raised on the Judge's initiative (it not having been pleaded). Judge Inglis QC noted that, if necessary, he would have been prepared to find for the insured on the basis of a Fair Trading Act breach stating: ${ }^{32}$

On the face of it the insurer's failure to make any direct inquiry as to the plaintiff's past, anticipating that her innocent failure to disclose it might later provide an excuse for avoiding the policy, is a situation that comes within the Fair Trading Act 1986, s 9, as conduct that is unlawful as "misleading or deceptive or is likely to mislead or deceive". ... Since it is a basic tenet of insurance law that the contract is one in which the utmost good faith must be shown by each party to the other, the concept of uberrimae fidei and the concepts in $s 9$, would seem to form a natural partnership. Section 9 is to be seen as adding a concrete dimension, by protecting the consumer, to the duty of utmost good faith owed by an insurer in holding itself out as ready to do business.

Subsequent Judges, however, have taken another view. In the High Court decision in Gate the insured argued, amongst other things, that the insurer's brochure and proposal gave the false impression that the insured would be specifically warned as to his legal duties, whereas, in fact there were undisclosed duties relating to non-disclosure and other matters. ${ }^{33}$ Interestingly, this was partly based on the argument that the policy was promised to be "plain language policy".

\footnotetext{
32 Above n 9, 39.
}

33 Above n 7, 74 . 
Fisher J rejected the argument saying, amongst other things: ${ }^{34}$

(a) There was nothing in the "plain language policy" argument;

(b) The insured's case really came down to an argument that insurance companies should take positive steps to warn insureds about disclosure obligations and:

(i) There was no such obligation at common law (and it would be difficult to impose one without basing it on some general principle which would apply to other types of contracts);

(ii) There was nothing inherently misleading about entering into a contract without first taking positive steps to advise the other party as to the law; and

(iii) Section 2(2) of the Fair Trading Act includes omissions as potentially misleading or deceptive conduct. However, omissions are included only where, taken in context, positive conduct is misleading or deceptive by virtue of such omission.

In the Quinby decision, after a review of the relevant case law, Barker J reached a similar decision. He had two main reasons for rejecting the application of the Fair Trading Act; ${ }^{35}$ First, s 9 is similar to s 52 of the Australian Trade Practices Act 1974. However, in Australia, despite the availability of $s 52$ it was still thought necessary to enact $\mathbf{s} 22$ of the Insurance Contracts Act 1984 (providing for a specific duty on insurers to clearly inform the insured of the nature and effect of the duty of disclosure). If $\mathbf{s} 52$ of the Australian Trade Practices Act had covered the matter, that would not have been necessary. Consequently, s 9 must not cover the matter.

Second, the argument (raised in an early hearing on the Gate case) that applying the Fair Trading Act would cause an anomalous difference in the disclosure law between marine and general insurance situations. This was because $\mathbf{s} 50$ of the Fair Trading Act provides that the Act does not limit or affect the operation of other statutes. And, as the scope and operation of the duty of disclosure is specifically set out in the Marine Insurance Act 1908 for marine insurance contracts, it could therefore, arguably, not be affected by such a Fair Trading Act decision - although the common law applicable to other insurance contracts would be.

The approaches of Fisher J and Barker J have subsequently received some support. ${ }^{36}$ However, some of their arguments against the operation of the Fair Trading Act are

Above n 7, 76-77.

Above n 9, 44-45. 
debatable. The contract based arguments raised by Fisher J ((b)(i) and (ii) above) appear to be promulgated on the basis that an insurance contract is no different to any other contract and as there is no obligation to warn in other contracts there should be no obligation to warn in insurance contracts. However, most other contracts are not contracts uberrimae fidei. Also, to give that principle some substance vis a vis insurers, it seems entirely logical to require insurers, as a matter of good faith, to warn insureds of the consequences of their incomplete disclosure notwithstanding the limited nature of questions in the proposal form. As Judge Inglis $Q C$ stated in King the concept of uberrimae fidei and $s 9$ of the Fair Trading Act form a "natural partnership". ${ }^{37}$

Fisher J's argument on $\mathrm{s} 2$ (2) of the Fair Trading Act suggests that a failure to warn of wider disclosure obligations could not be misleading for the purposes of $s 9$, because there was no positive conduct made misleading by virtue of such omission. Whether or not that is a correct statement of the law, factually it seems positive conduct (ie. the proffering of a proposal in limited terms) is made misleading by the failure to warn omission.

Barker J's argument that s 52 of the Australian Trade Practices Act 1974 was apparently not sufficient to negate the need for $\mathbf{s} 22$ of the Insurance Contracts Act 1984 (Cth) would be more convincing if legislators always ensured there was no overlap in the legislative protections available to complainants. That, however, is not the case. Also, the Insurance Contracts Act 1984 (Cth) has approximately 78 sections dealing, as one would expect, with a multiplicity of issues. It is not surprising in such a comprehensive piece of legislation that this obligation was included. It is not as if $s 22$ was specifically enacted to fill the gap left by the Trade Practices Act 1974 .

The argument based on potential anomalies between general and marine insurance contracts, it could be argued, places undue weight on the importance of the Marine Insurance Act 1908 in the wider insurance field. Protection of by far the largest class of insurance population should not be watered down by a potential inconsistency between a statute dealing with a relatively limited class of insured and the common law. In addition, the practice of placing "glosses" on statutory wordings is not unfamiliar to our judiciary. They may very well find a way to impose a consistent duty to warn in both cases.

Therefore, whilst some judges have dismissed Fair Trading Act arguments in factual circumstances where there was little merit on the insured's side, it should not be considered that the argument, in an appropriate case, may not succeed. If insurers wished to reduce the chances of such a Fair Trading Act allegation being levelled against them, it would no doubt assist to include a warning in their proposals as to the scope of the duty of disclosure (as suggested above in relation to the good faith argument). 


\section{Waiver}

An insurer may, from the statements and questions contained in documents such as the proposal, be taken to have waived any general duty to provide further disclosure. Waiver will not, however, be easily presumed. ${ }^{38}$ A simple failure to ask a question on a specific point is unlikely to result in a waiver. ${ }^{39}$ As stated in the Peake decision:40

While the general duty is not displaced simply by the absence of specific questions, it is also settled that those specific questions which are asked may operate to limit, vary or even waive the general duty.

A common example of waiver is where an insured is specifically asked for details of any convictions obtained in the past five years. There, the need to disclose information on convictions obtained in the past six to ten years and so on, is waived - whether or not such earlier convictions would have been material to a prudent insurer. Whether the questions asked by an insurer result in a waiver depends on whether "a reasonable person reading the form would be justified in thinking that the insurer had restricted its right to receive all material information".41 A series of questions in a proposal on motor vehicle offences has resulted in a waiver of the duty to disclose other convictions. ${ }^{42}$

It has also been held that the obligation on insureds may become a subjective one (to disclose what the insured believes is material) where proposals finish off with general declarations with terms such as "to the best of my knowledge" (there is no further information likely to affect the risk) or "I have not withheld" (any information). ${ }^{\mathbf{4 3}}$

If insurers wish to avoid a subjective test being applied, care must be taken in the wording of such catchall questions or declarations. One suggestion for keeping the duty objective is discussed in Hanham: ${ }^{\mathbf{4 4}}$

Had the appellant wished to retain the objective test as to materiality it could easily have simply asked the question "Is there any further information likely to affect the acceptance of this insurance?". Similarly the declaration signed by the respondent immediately after

38 E R Hardy Ivamy General Principles of Insurance Law (6 ed, Butterworths, London, 1993) 157.

39 See, Misirlakis, above n 3, 78,896; McHale, above n 1, 408-409 or 77,435; Quinby, above n 9, 33-39.

40 Above n 28, 291.

41 State Insurance Ltd v Fry (1991) 6 ANZ Ins Cas 77, 237, 77, 238. See also, Quinby, above n 9, 32.

42 State Insurance General Manager v Hanham (1990) 6 ANZ Ins Cas 76,601. See also Peake, above n 28.

43 See King above n 9; Fry, above n 41; Hanham, above n 42; Peake, above n 28; but see also Wayne Wilkinson Insurance, above $\mathrm{n} 36$, where a different decision was reached.

44 Above n 42, 76,608. 
completing the questions could have deleted the phrase "that to the best of my knowledge and belief [the particulars and answers given above were correct]".

Perhaps, however, the high point of the no waiver type situation is illustrated in Quinby. There, the need to disclose criminal convictions (and other matters) was held not waived, even though the questionnaire signed by the insured did not enquire about criminal convictions, or contain any general question inviting disclosure of material facts or declaration that the insured had not withheld any information likely to affect acceptance of the proposal.

Quinby clearly demonstrates the principle that waiver will not operate simply where no question has been asked about a matter. Waiver will only be construed from specific questions or statements in the form. This principle is a well established one. However, logically, it is difficult to see the difference between a situation where an insured is led to believe that general convictions are not relevant due to a series of questions being in the proposal about traffic convictions, and the situation (as in Quinby) where the insured is led to believe that convictions are not relevant at all by the proposal only containing questions on entirely different matters.

\section{E General}

What is perhaps most surprising, and very fortunate for insurers, is the generally poor reception the good faith, Fair Trading Act and waiver arguments have had in the past (although a glimmer of light appears in the Gate Court of Appeal decision). In these days where consumer protection is becoming ever more prevalent (through Acts such as the Fair Trading Act and the Consumer Guarantees Act) there seems to be a sizeable gap in the obligations on insurers in the disclosure context.

It might be argued that Principle 3(f) of the Privacy Act was a piece of "consumer protection legislation" designed to assist. Principle 3(f), relating to the collection of information from individuals, provides that where information is being collected, the collector must advise the individual of the consequences if all or any of the information "requested" is not provided. However, (except where there is overlap between mis-statement and non-disclosure) it does not neatly fit the non-disclosure context. Disclosure law relies upon information to be volunteered. The information is not requested. An appropriate "judicial gloss" might overcome that problem. There are, however, limits to the extent an individual is entitled to enforce Privacy Act breaches. These may, in any event, make that remedy less practical to an insured. ${ }^{45}$

45 See for example, ss $66,73,77,79$ and $82-86$. 
Again, in Australia, some of these problems have been specifically addressed in legislation. To avoid insureds being "caught out" through ignorance of disclosure law, s 22 of the Insurance Contracts Act 1984 (Cth) provides:

(1) The insurer shall, before a contract of insurance is entered into, clearly inform the insured in writing of the general nature and effect of the duty of disclosure ...

(3) An insurer who has not complied with subsection (1) may not exercise a right in respect of a failure to comply with the duty of disclosure unless that failure was fraudulent.

There seems to be considerable merit in New Zealand adopting such a provision and, again, there is considerable judicial comment to that effect. ${ }^{46}$

\section{CONCLUSION}

Generally, any conduct going to moral hazard and therefore potentially affecting the risk requires disclosure from an insured. It is irrelevant whether that moral hazard is represented in a conviction, a wrongful acquittal, a pending charge or undetected conduct.

The privilege against self-incrimination and/or the presumption of innocence should not relieve the insured from the obligation. Arguably, the privilege should also not be available in any civil proceedings arising from the insurance contract.

Whilst the obligation to disclose places a significant onus on an insured, it is inevitable that the onus will eventually be watered down either by the courts, or the legislature, recognising a duty to warn or adopting the reasonable insured test.

Until such changes occur, there is a good argument to say that New Zealand law on this area is out of kilter with its own consumer focused legislation.

46 See Quinby, above n 9, 44; Gate, above n 30, 76. 